\title{
Stereological Evaluation of Temporal Lobe/Telencephalon Volume in Temporal Lobe Epilepsy Using the Cavalieri Principle
}

\section{Temporal Lob Epilepsisinde Temporal Lob/Telencephalon Hacim Oranının Cavalieri Yöntemi Kullanılarak Stereolojik Ölçümü}

\begin{abstract}
AIM: Epilepsy is a temporary electric discharge in the brain cells due to shortterm brain function disorder. Epileptic seizures mostly stem from the temporal lobe. The prevalence is the same for women and men. It is thought that there are both microscopic- and macroscopic-level localized changes in the temporal lobe epilepsy. This study aims to assess the volumetric changes that might occur in temporal lobe epilepsy and compare these with normal brains.

MATERIAL and METHODS: Volumetric assessment of temporal lobes and telencephalons was performed using the stereological method on the magnetic resonance images (MRI) of 30 female temporal lobe epilepsy patients and 30 healthy females (control group). The volume ratio of temporal lobe to the whole telencephalon was calculated by means of the Cavalieri principle over the coronal MR images of all participants. The section images were transformed into a series of images by Image j program and the measurements were performed by using a point grid.
\end{abstract}

RESULTS: The patient group's temporal lobe/telencephalon volumetric ratios were found to be significantly lower than that of the normal participants.

CONCLUSION: The pattern of temporal lobe volume decrease in TLE may be due to a combined effect of the electrical discharges during seizures and secondary damage due to disconnection.

KEYWORDS: Temporal lobe epilepsy, Magnetic resonance imaging, Temporal lobe, Stereology

\section{ÖZ}

AMAÇ: Epilepsi kısa süreli beyin fonksiyon bozukluğuna bağlı beyin hücrelerinde geçici anormal elektrik yayılmasıdır. Epilepsi nöbetleri en çok temporal lobdan kaynaklanmaktadır. Kadın ve erkeklerin hastalığa yakalanma oranları eşittir. Temporal lob epilepsisinde beyinde gerek mikroskobik gerekse makroskobik düzeyde lokalize değişikliklerin olduğu düşünülmektedir. Bu çalışmanın amacı, Temporal lob epilepsili hastaların beyinlerinde oluşabilecek hacimsel değişikliklerin değerlendirilmesi ve bunların normal beyinler ile karşılaştırılmasıdır.

YÖNTEM ve GEREÇ: Çalışma Temporal lob epilepsili erişkin 30 kadın hasta ve 30 sağlıklı kadın (kontrol grubu) üzerinde gerçekleștirildi. Bireylerin hiçbirinde yer kaplayan lezyon veya serebrovasküler bir hastalık bulunmamaktaydı. Tüm bireylerin koronal düzlemde alınmıș MR görüntüleri üzerinden stereolojik olarak Cavalieri prensibi kullanılarak temporal lobun tüm telensefalona olan hacim oranı hesaplandı. Kesit görüntüleri Imaje j programında görüntü dizisi haline getirildi ve noktalı alan ölçüm cetveli kullanılarak ölçümler gerçekleştirildi.

BULGULAR: Hasta bireyler ile normal kişilerin temporal lob/telencephalon hacimsel oranları karşılaştırıldığında hasta grupta hacimsel oranların sağlıklı gruba göre anlamlı olarak düşük olduğu tesbit edildi.

SONUÇ: Temporal lob epilepsisinde temporal lob hacmindeki azalmanın sebebi anormal elektiriksel deşajların beyinde verdiği etkiye bağlı olabilir.

ANAHTAR SÖZCÜKLER: Temporal lob epilepsi, Manyetik Resonans Görüntüleme, Temporal lob, Stereoloji
Ayla KURKCUOGLU

Ragıba ZAGYAPAN

Can PELIN

Baskent University, Faculty of Medicine,

Department of Anatomy, Ankara, Turkey

Received : 05.04.2010

Accepted : 21.05.2010

The data of the study was used in the twoposter presentation at the 10th Congress of the European Association of Clinical Anatomy, September 2009, Istanbul, TURKEY

Correspondence address: Ayla KURKCUOGLU

Department of Anatomy, Faculty of Medicine, Baskent University, 06530 Baglıca Ankara, TURKEY Phone : +90 31223410 10- 1524 Fax : : +90 3122341180

E-mail : kayla@baskent.edu.tr aylakurkcuoglu@gmail.com 


\section{INTRODUCTION}

The telencephalon, the largest section of the central nervous system, is placed inside the cranium and comprises two hemispheres. Each hemisphere consists of gyri or lobulus sections separated from each other by hollow or shallow grooves. These structures increase the surface area of the cerebral cortex significantly. In this way, the surface of cortex cerebri may reach $2000-2500 \mathrm{~cm} 2$ in an adult $(12,20)$. Each hemisphere is divided into five lobes with hollow grooves: frontal lobe, parietal lobe, temporal lobe, occipital lobe and insula (19). The temporal lobe is separated from the front section of the parietal, frontal and occipital lobes by the lateral sulcus. The temporal lobe hosts structures related to hearing center, recognition and evaluation of objects seen, smell area, expression of emotions and memory (25).

The brain consists of many neurons and has a complex working system that possesses a lot of secrets despite advancing technology. One of these secrets is epilepsy. Epilepsy may be defined as the repetitive disorders of the neuron groups in the central nervous system emerging due to abnormal electric discharge for various reasons and is a serious and common neurological condition (17). It is seen 10 times more frequently than multiple sclerosis and 100 times more frequently than motor neurone disorders. Its prevalence in the society is $0.5-1 \%$ (18). There is no identifiable etiological factor in approximately $60 \%$ of all the cases. However, congenital anomalies, genetic tendencies, tumor, meningitis, infection, ischemic lesions, thyroid disorders, trauma and nutritional disorders are the leading causes $(5,14)$. Epilepsy types may be classified as temporal, parietal, frontal and occipital lobe epilepsies depending on the lobes affected by the brain. The temporal lobe epilepsy (TLE) prevalence rate is nearly the same in women and men (7). The prevalence of TLE among other epilepsy types is around 30-35\% (27,29). In TLE, disorders can be seen in the individual's functions such as hearing, smell, emotional behavior and memory (22).

It is known that there are both microscopic- and macroscopic-level localized changes in the brain in TLE. Hippocampal atrophy, decrease in the gray and white matter volume in the epileptic area, volume loss in entorhinal cortex, volume loss in posterior collosal areas and medial temporal lobe atrophy have been reported in various related studies $(6,13,16)$. In these studies, a volume measurement was conducted in a certain anatomic structure. However, the (reference) volume of the components in a structure and the ratio of these structures to the volume they are inside or to each other may provide significant information (8). A series of methods are used in order to calculate the total volumes of organ or structures of their components. If the structures cannot be isolated from the components in their environment, Cavalieri's principle, which is a stereological method, can be used in a reliable way. Cavalieri's principle is the most frequently used volume calculation method among stereological methods (26). The present study aims to make a comparison of sides by calculating the temporal lobe/telencephalon volume ratio values, which has not been performed in TLE patients before, and compare them with the volume ratios obtained from normal people as well.

\section{MATERIAL and METHODS}

This study was conducted retrospectively in Ankara Oncology Education and Research Hospital with the consent of the ethics committee. The research was conducted on the MR images of 30 female left TLE patients (mean age $29 \pm 10$ year, range $=25-37)$ with complex partial seizures due to a temporal source and 30 healthy women (mean age $27 \pm 11$ year, range $=26-38$ ). All controls were interviewed in order to exclude those with neurological diseases. All patients were referred from the outpatient epilepsy clinic of our institution, where they were diagnosed by a detailed neurological evaluation. The nature of the epileptic syndrome was based on ILAE criteria (1). The majority of the patients had visited a neurologist at the Epilepsy Unit of the Department of Neurology regularly since the time of their epilepsy diagnosis. Moreover, at the time of the MRI, all patients were examined by a neurologist at the Epilepsy Unit. The diagnosis and the etiological factors of TLE were evaluated on the basis of medical history, neurological examination, electroencephalography (EEG), and qualitative MRI. Seizure symptomatology and non-invasive EEG data were used to determine the laterality of TLE. None of the participants had a space-occupying lesion or cerebrovascular disorder and all of them were righthanded. 
Consecutive $0.7 \mathrm{~cm}$ thick serial MRIs from sagittal T1-weighed images with SE T1A (TR 500-700 $\mathrm{ms}$; TE 10-10-30 ms) were obtained to estimate telencephalon volume and temporal lobe volumes. The whole telencephalon volume and temporal lobe volume was estimated from each image using the point-counting technique. All measurements were performed while blinded to subject details and the results of any other measurements.

The original MRI was exported as tiff image files and further stereological analysis were done using these image sets with the aid of Image-J software. A uniform point-grid with a point-associated area of $0.123 \mathrm{~cm} 2$ was randomly superimposed on each MRI using the "Grid" (300) plug-in of Image-J. Points hitting the cerebral hemispheres and temporal lobes were manually counted for area estimation of the cerebral profiles. Automated area estimation by manual perimeter tracing generally takes too much time and hence, the more rapid point counting method was preferred. Volume estimation was accomplished by the Cavalieri's principle as described previously using the formula given below (8):

$$
\mathrm{V}=\mathrm{t} \times[((\mathrm{SU}) \times \mathrm{d}) / \mathrm{SL}] 2 \times{ }^{\mathrm{TM} P}
$$

where, $t$ is the section thickness, $\mathrm{SU}$ is the scale unit, $\mathrm{d}$ is the distance between two points in the point grid, SL is the Scale Length and ${ }^{\text {TMP }}$ is the total number of points counted for one individual. The expression $[((\mathrm{SU}) \times \mathrm{d}) / \mathrm{SL}]$ gives the real area represented by each point at the original tissue level independent of magnification. All data were entered to a previously-prepared Microsoft Excel spreadsheet for automatic calculation of both the results of the above formula and the statistical evaluation parameters including the nugget variance and the coefficient of error (CE).

In order to find the volume ratio that the components cover in comparison with the whole structure, it is necessary to detect the rate at which the points disperse between the reference volume and components. To this end, a grid, containing points of appropriate frequency are placed on the related section image randomly and the projections of the component (temporal lobe) and the number of points matching the whole reference volume (all telencephalon including the temporal lobe) are determined. When the two values are proportioned with each other, the volume of the related component in comparison with the reference volume, which is the component's volume ratio, is calculated objectively. Here, only the number of points is necessary; it is not necessary to know about the section thickness values and as a result, the obtained value is a ratio without unit.

All the individuals studied under the study were measured twice by the researcher and two ratio values were obtained from each individual. According to the reliability analysis performed using these data, the intraclass correlation coefficient values in both groups are at a significantly high level $(\mathrm{r}=0.93-0.97$, all $\mathrm{P}<0.001)$.

\section{RESULTS}

In this study, the temporal lobe and telencephalon volumes of 30 female left TLE patients monitored for 8-10 years and 30 healthy females were evaluated separately on the basis of the stereological counting method. The temporal lobe/telencephalon volume was obtained as a result of the volumetric values. The values belonging to the patients and healthy females are presented in Table I.

In assessments of left TLE patients, the ratio of right temporal lobe/telencephalon volume ranged between $12 \%$ and $16 \%$ while left temporal lobe/telencephalon volume ranged between $11 \%$ and $14 \%$. In measurements conducted with healthy people, the right temporal lobe/telencephalon values varied between $11 \%-19 \%$, whereas the left temporal lobe/telencephalon volume values varied between $11 \%-18 \%$. No significant difference was found in a comparison of the right and left volume ratios in healthy people (Table I, Figure 1). It was observed that the left temporal lobe/telencephalon volume is lower than that of the right in the patients. In comparisons between healthy people and patients, the obtained results slightly differed. The fact that both groups did not differ in terms of right lobe volume values, yet there was a significant difference between the left lobes was noted (Table I, Figure 2). As can be seen, the left lobe volumes of the patient group are smaller than that of the healthy group. This finding shows that the disorder might have caused a volumetric decrease in the left temporal lobe.

\section{DISCUSSION}

It is known that there are macroscopic- or microscopic-level volumetric and structural changes 
Table I: Values of Right and Left Temporal Lobe/Telencephalon Volumes

\begin{tabular}{|l|c|c|c|c|c|}
\hline & \multicolumn{2}{|c|}{$\begin{array}{c}\text { Right Temporal lobe/ } \\
\text { Telencephalon }\end{array}$} & \multicolumn{2}{c|}{$\begin{array}{c}\text { Left Temporal lobe/ } \\
\text { Telencephalon }\end{array}$} & \\
\hline & Mean & SD & Mean & SD & Z \\
\hline Patients & 0.141 & 0.141 & 0.129 & 0.114 & $3.68^{* * *}$ \\
\hline Controls & 0.140 & 0.197 & 0.143 & 0.208 & 1.70 \\
\hline & \multicolumn{2}{|c|}{ Patients } & \multicolumn{2}{|c|}{ Controls } & \\
\hline & Mean & SD & Mean & SD & Chi-square \\
\hline Right Temporal lobe/telencephalon & 0.141 & 0.141 & 0.140 & 0.197 & 0.027 \\
\hline Left Temporal lobe/telencephalon & 0.129 & 0.114 & 0.143 & 0.208 & $6.050^{* *}$ \\
\hline
\end{tabular}

${ }^{* *} P<0.01,{ }^{* * *} P<0.001$

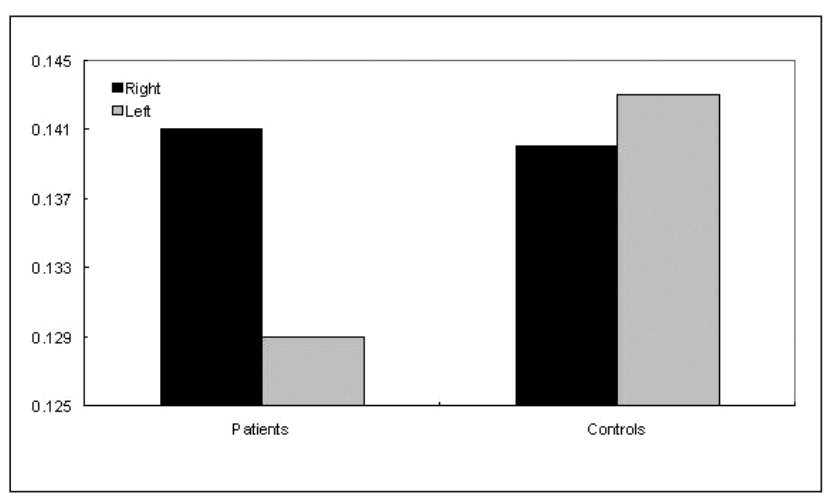

Figure 1: Right and left side comparison of the temporal lobe/telencephalon volume in controls and patients.

in brain's hemispheric structures due to TLE or various other factors $(22,27,29)$. The seizures of the TLE cases which are resistant to medical therapy and have temporal lobe atrophy according to MRI can be controlled with surgical treatment. In this sense, the identification of the temporal lobe lateralization prior to surgery is significant in terms of operation type and efficiency (9). There is no difference between women and men in terms of TLE prevalence (3). The researchers analyzed temporal lobe/telencephalon volume changes in healthy women and patients comparatively. This study aimed to investigate the temporal lobe/telencephalon volume changes of female patients monitored for at least five years and it was observed that in TLE patients there was a significant decrease in the section diagnosed with TLE in terms of temporal lobe/telencephalon volume compared with both healthy people and their own healthy parts.

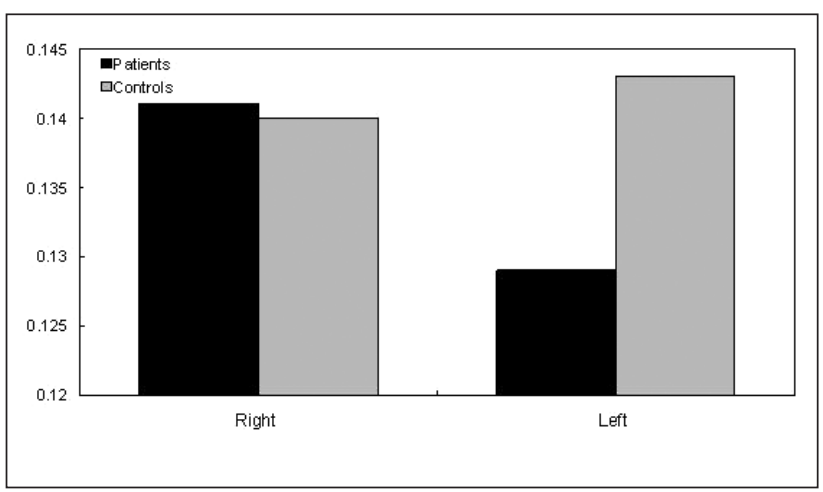

Figure 2: Values of right and left temporal lobe/telencephalon volume in patients compared to controls.

Various studies have been conducted over the volumetric differences in TLE patients. In these studies, gray matter-white matter losses, hippocampus atrophy, entorhinal cortex volumetric changes, medial temporal atrophy and corpus collosum structural differences were investigated $(5,13,16,27,29)$. However, these volumetric changes were only structurally analyzed and the proportional volume changes were not considered. The volume of components inside a structure or the ratios of these to each other or the total volume (eg. telencepaphalon) are parameters which provide crucial information. Cavalieri's principle may be used reliably and with ease in this evaluation. In order to find the volume ratios of the component structure to the whole organ, it is necessary to determine the rate at which the calculated points in point grid disperse between the reference volume and the components. The volumetric rate or real volume of a structure or organ may differ from 
person to person due to various reasons. However, the volumetric ratio of the structure does not differ from person to person or differs at a minimal rate $(8,26)$. In light of this important information, the temporal lobe/telencephalon volume ratio changes in TLE patients, which were previously not shown, were analyzed and compared with the results of various studies.

Garcia et al. analyzed whether TLE patients had hippocampal atrophy or not using MR images and Cavalieri's principle. In their study, they stated that the major damage of TLE patients was in the hippocampus of the side opposite to the epileptic side and right TLE patients had a higher probability of having bilateral hipocampal atrophy than left TLE patients. In the study which included 101 patients, they pointed out that 7 patients did not have hippocampal atrophy (10). In their morphometric study of medial TLE patients, Lee et al. noted a decrease in white and gray matter thickness in the site which had the epileptic focus (15). In a similar study, Bernasconi et al. investigated how the temporal lobe's grey and white matter thickness changed separately in TLE patients. In the study which included 85 patients, they stated that the gray and white matter decreased depending on the side where TLE was located on the basis of the measurement results obtained by means of radiological methods on MRI images. Gray matter and white matter thicknesses were found to be thicker on the side (opposite hemisphere) opposite the TLE side (2).

Morphological changes can also be observed in the corpus collosum structure depending on the epilepsy starting age and the affected hemisphere. Weber et al. demonstrated a decrease in the thickness of posterior collosal areas in epilepsy. In this study, a decrease was observed in posterior colossal areas' thicknesses in patients who had early starting age and had especially left hemisphere diagnosis (28). In another study conducted with epileptic rats whose temporal lobe cortex was exposed to damage, a decrease in hearing ability and a noticeable decrease in cortex thickness was observed $(10,15)$. Volumetric measurements were also performed in TLE patients' hippocampus, amygdala and parahippocampal areas using the MRI imaging method. Bernasconi et al. detected atrophy in each of the three areas studied in their study (2). Bonilha et al. demonstrated that the left entorhinal and left perirhinal cortex volume of the left medial TLE patients decreased, whereas in right medial TLE patients the right entorhinal and perirhinal cortex volume decreased (4). Similarly, Salmanpera et al. studied the same topic and stated that entorhinal cortex damage correlated with TLE $(23,24)$.

All of these studies have demonstrated that macroscopic and microscopic changes take place in the brain of patients diagnosed with TLE due to various reasons. However, these changes were analyzed structurally in the organs and the volumetric changes were not mentioned. Since it was thought that the volumetric changes were more significant, we first measured the whole temporal lobe volume in both hemispheres on the basis of TLE patients' MRI images using the stereological method. Then, the telencephalon volumes were measured and the comparisons were made with the ratio values. Many authors also evaluated volume changes of temporal lobe according to age and genders. They claimed that female subjects had significantly smaller temporal lobe volumes compared to males of similar age. However, this study was conducted with only female patients and healthy women in similar age groups regardless of sex discrimination. Since the study was retrospective, there was no chance of conducting etiological research like febrile convulsion trauma, premature birth or familial epilepsy history. Yet, the patients had epilepsy histories of at least five years. The aim of determining this period was the low probability of entorhinal damage and hipocampal atrophy in the first five years $(23,24)$.

In line with the literature, no difference was observed in the right and left side volumetric ratios in healthy people while it was seen that right temporal lobe/telencephalon ratio was higher in left TLE patients (right temporal lobe; $0.141 \pm 0.141$, left temporal lobe; $0.129 \pm 0.114$ ). In order to understand the reason for this change, the telencephalon volumes were reanalyzed. It was found that there was no significant difference between right and left telencephalon volumes in the patients. On this basis, it was thought that the ratio difference was due to the decrease in left temporal lobe volume in patients. Although the volumetric evaluations are within the same age group and same sex in anatomic structures, 
they may exhibit multiple variations. However, the ratio of a structure to the total volume is an important parameter which provides significant information $(11,23,24)$.

In conclusion, it was demonstrated that there was a significant decrease in temporal lob/telencephalon ratio in TLE patients. The pattern of temporal lobe volume decrease in TLE may be due to a combined effect of the electrical discharges during seizures and secondary damage due to disconnection. The pertinence of these widespread changes in temporal lobe epilepsy cases with respect to clinical parameters, such as outcome after surgery, remains to be evaluated.

\section{REFERENCES}

1. Alan JL: Diagnostic criteria in Neurology (Ed). AJ Lerner, Totowa NJ: Humana Press Inc 2006: 79-82

2. Bernasconi N, Bernasconi A, Caramanos Z, Antel SB, Andermann F, Arnold DL: Mesial temporal damage in temporal lobe epilepsy: a volumetric MRI study of the hippocampus, amygdala and parahippocampal region. Brain 126: 462-469, 2003

3. Bilginer B, Akalan N: Temporal lobe epilepsies. Turkish Neurosurgery Journal 16:156-159, 2006

4. Bonilha L, Kobayashi E, Rorden C, Cendes F, Li L: Medial temporal lobe atrophy in patients with refractory temporal lobe epilepsy. J Neurol Neurosurg Psychiatry 74:1627-1630, 2003

5. Bonilha L, Rorden C, Castellano G, Pereira F: Voxel-based morphometry reveals gray matter network atrophy in refractory medial temporal lobe epilepsy. Arch Neurol 61: 1379 - 1384, 2004

6. Bonilha L, Rorden C, Appenzeller S, Coan A, Cendes F, Li M: Gray matter atrophy associated with duration of temporal lobe epilepsy. NeuroImage 32: 1070-1079, 2006

7. Breier JI, Leonard CM, Bauer RM, Roper S, Lucas TH, Gilmore RL: Quantified volumes of temporal lobe structures in patients with epilepsy. J. Neuroimaging 6:108-114, 1996

8. Canan S, Bünyamin Ş, Odacı E, Ünal B, Bilgiç S, Kaplan S: A Stereological Method for calculating total volume, volumetric density and volumetric ratio: Cavalieri principle. T Klin J Med Sci 22: 7-14, 2002

9. Cendes F, Leproux F, Melanson D, Ethier R, Evans A, Peters T, Andermann T: MRI of amygdala and hippocampus in temporal epilepsy. J Comput Assisted Tomogr 17:206-210, 1993

10. Garcia FM, Denby C, Keller S, Wieshmann U, Roberts N: Degree of hippocampal atrophy is related to side of seizure onset in temporal lobe epilepsy. AJNR 27: 1046-1052, 2005

11. Geinisman Y, Gundersen HJ, van der Zee E, West MJ: Unbiased stereological estimation of the total number of synapses in a brain region. J Neurocytol 25: 805-19, 1996

12. Jack CR, Sharbrough FW, Twomey CK, Cascino GD, Hirscihorn KA, Marsh WR, Zinsmeister AR, Scheithauer B: Temporal lobe seizures: Lateralization with MR volume measurements of the hippocampal formation. Radiology 175:423-429, 1990
13. Keller SS, Wieshmann U, Mackay C, Denby C, Webb J, Roberts $\mathrm{N}$ : Voxel based morphometry of grey matter abnormalities in patients with medically intractable temporal lobe epilepsy: effects of side of seizure onset and epilepsy duration. J Neurol Neurosurg Psychiatry 73: 648-656, 2002

14. Keller SS, Wilke M, Wieshmann UC, Sluming VA. Roberts N: Comparison of standard and optimized voxel-based morphometry for analysis of brain changes associated with temporal lobe epilepsy. NeuroImage 23: 860 - 868, 2004

15. Lee JW, Reutens DC, Dubeau F, Evans A, Andermann F: Morphometry in temporal lobe epilepsy. Magn Reson Imaging 13:1073-1080, 1995

16. Lin J, Salamon N, Lee A, Dutton R, Geaga J: Reduced Neocortical thickness and complexity mapped in mesial temporal lobe epilepsy with hippocampal sclerosis. Advance Access Publication 17:2007-2018, 2006

17. Mamourian A, Cho C, Saykin A, Poppito N: Association between size of the lateral ventricle and asymmetry of the fornix in patients with temporal lobe epilepsy. AJNR Am J Neuroradiol 19: 9 -13, 1998

18. Mathern GW, Babb TL, Pretorius JK, Melendez M, Lévesque MF: The pathophysiologic relationships between lesion pathology, intracranial ictal EEG onsets, and hippocampal neuron losses in temporal lobe epilepsy. Epilepsy Res 21:133-147, 1995

19. Moore KL, Dalley FA: Clinically oriented anatomy. 4th ed. Philadelphia ,Pennsylvania 2000: 213-218

20. Nakasu Y, Nakasu S, Morikawa S: Diffusion-weighted MR in experimental sustained seizures elicited with kainic acid. Am J Neuroradiol 16:1185-1192, 1995

21. Pakkenberg B, Gundersen HJ: New stereological method for obtaining unbiased and efficient estimates of total nerve cell number in human brain areas. Exemplified by the mediodorsal thalamic nucleus in schizophrenics. APMIS 97: 677-681, 1989

22. Rose G, Diamond D, Pang H, Dunwiddie T: Primed burst potentiation: Lasting synaptic plasticity invoked by physiologically patterned stimuli. Berlin: Springer-Verlag, 1998:96-98

23. Salmenperä T, Kälviäinen R, Partanen K, Pitkänen A: Hippocampal damage caused by seizures in temporal lobe epilepsy. Lancet 351:35, 1998

24. Salmanpera T, Almanper A, Reetta K, Ailen A, Pitk A: Quantitative MRI volumetry of the entorhinal cortex in temporal lobe epilepsy. Seizure 9: 208-215, 2000

25. Savas HA, Unal B, Erbagci H, Inaloz S, Herken H, Canan S, Gumusburun E, Zoroglu SS: Hippocampal volume in schizophrenia and its relationship with risperidone treatment: a stereological study. Neuropsychobiology 46:61-66, 2002

26. Snell RS: Clinical anatomy for medical students 5 th ed. Boston (MA): Little Brown, 1997:755-770

27. Szabo' C, Lancaster J, Lee S: MR Imaging volumetry of subcortical structures and cerebellar hemispheres in temporal lobe epilepsy. AJNR Am J Neuroradiol 27:2155- 2160, 2006

28. Weber B, Luders E, Faber J, Richter S, Quesada CM, Urbach H, Thompson PM, Toga AW, Elger CE, Helmstaedter C: Distinct regional atrophy in the corpus callosum of patients with temporal lobe epilepsy. Brain 130: 3149-3154, 2007

29. Wolf R, Alsop D, Reis I, Meyer P, Maldjian J, Atavales J, French J, Alavi A: Detection of mesial temporal lobe hypoperfusion in patients with temporal lobe epilepsy by use of arterial spin labeled perfusion MR imaging. AJNR Am J Neuroradiol 22:1334-1341, 2001 